\title{
The relevance of IL-1 $\beta$ and IL-1RN gene polymorphisms in the etiology of preterm delivery in the population of Polish women
}

\author{
Magdalena Barlik' ${ }^{1}$ Aleksandra E. Mrozikiewicz² Elzbieta Drews-Piasecka $^{3}$, \\ Grazyna Kurzawinska ${ }^{1}$, Zbyszko Malewski ${ }^{1}$, Krzysztof Drews ${ }^{1}$ \\ ${ }^{1}$ Department of Perinatology and Women's Diseases, Poznan University of Medical Sciences, Poland \\ 'Students' Association at the Department of Infertility and Reproduction Endocrinology, \\ Poznan University of Medical Sciences, Poland \\ ${ }^{3}$ Department of Gynecology and Obstetrics, Provincial Hospital in Poznan, Poland
}

\begin{abstract}
Objectives: Preterm delivery (PTD) is one of the important challenges for perinatal medicine due to prematurity and associated complications. The mechanisms leading to the PTD occurrence are not fully clarified and it is assumed that PTD is a complex phenomenon caused by many different pathophysiological factors. Nowadays, an important role is attributed to genetic determinants of PTD, pointing to possible relevance of polymorphic variants of candidate genes to participate in the etiology of PTD. The aim of the study was to assess the relevance of $+3953 C>T I L-1 \beta$ and 86 bp VNTR IL-1RN gene polymorphisms in the etiology of PTD in Polish women.

Material and methods: Study group consisted of 150 women (mean age $29.2 \pm 5.6$ years, mean weeks of gestational age $33.7 \pm 2.8 \mathrm{gw}$.) with preterm delivery ( $22+0-36+6 \mathrm{gw}$.). To the control group 150 healthy pregnant women (mean age $29.0 \pm 3.7$ years, mean weeks of gestational age $39.3 \pm 1.2 \mathrm{gw}$.) who delivered $>37 \mathrm{gw}$. were enrolled. All investigated polymorphisms were analyzed by polymerase chain reaction (PCR) and restriction fragment length polymorphism (RFLP). Results: The interesting observation was the notice of overrepresentation of $2 / 2$ genotype of IL-1RN gene in the control group ( 8.0 vs. $3.3 \%, p=0.06$ ) and 2 allele in the control group ( 25.0 vs. $20.0 \%, p=0.07)$.

Conclusions:

1. The $+3953 C>T$ polymorphism of $I L-1 \beta$ gene probably is not connected with the risk of preterm delivery

2. The study results points to the possible modulating effect of mutated IL-1RN* 2 allele ( $86 b p$ VNTR polymorphism) of IL-1RN gene in decreased risk of preterm delivery.

Key words: preterm delivery; genetic variants; interleukin
\end{abstract}

\section{INTRODUCTION}

Preterm delivery (PTD) is one of the important challenges of perinatal medicine due to prematurity and associated complications. The mechanisms leading to the PTD occurrence are not fully clarified and it is assumed that PTD is a complex phenomenon caused by many different pathophysiological factors.

Nowadays, an important role is attributed to genetic determinants of PTD, pointing to possible relevance of polymorphic variants of candidate genes to participate in the etiology of PTD. It is being thought that in the PTD about 300 different genes are involved. These genes concern fetal growth and development, hormonal metabolism, uterus contractions, the endurance of amniotic membranes as well as cervical flexibility. Lately, more and more often genes involved in inflammatory response and reactions are believed to take part in the etiology of PTD [1-3].

Interleukine-1 (IL-1) is one of the most important regulators of inflammatory response influencing on almost all types of cells [4]. There are two different genes encoding 
IL-1: IL-1alpha and IL-1beta (2q14, 2q21). Mature proteins are homological only in $25 \%$ of amino-acid sequence, but its spatial structure is very similar [5].

Interleukin-1 receptor antagonist (IL-1 RA) is a protein binding to IL-1 receptors (IL-1R1 and IL-R2). IL-1RA protein is encoded by IL-1RN gene (2q14.2). VNTR type polymorphism (variable number of tandem repeats) of IL-1RN gene is caused by the presence in intron 2 various number of tandem 86 bp repeats. The most frequent type is variant containing 4 repeats named IL1RN*1. But there are also variants with 2 repeats (allele IL1RN*2), 3 repeats (allele IL1RN*4), 5 repeats (allele IL1RN*3) and 6 repeats (allele IL1RN*5) [6]. In 2002 Vamvakopoulus revealed the sixth variant of this polymorphism containing only one copy of 86 bp sequence (allele IL1RN0) [7].

\section{Aim of the study}

The aim of the study was to assess the relevance of +3953 C > TIL-1 $\beta$ and 86 bp VNTR IL-1RN gene polymorphisms in the etiology of preterm delivery in the population of Polish women.

\section{MATERIAL AND METHODS}

To the study group 150 patients with PTD were enrolled. The inclusion criteria were as follows: delivery between $22+0-26+6$ gestational week, clinical signs of PTD (regular uterus contractions, lower abdominal pain, cervical dilatation) or preterm premature rupture of membranes, singleton pregnancy, Caucasian race, Polish citizenship. The whole study group was divided into three subgroups according to the gestational week of PTD: a). 22-28 gw, b). 28-32 gw, c). 32-36 gw. The control group consisted of 150 healthy women whose pregnancy ended with delivery of a healthy newborn at term. The inclusion criteria were as follows: pregnancy ended $>37+0 \mathrm{gw}$, singleton pregnancy, the proper course of pregnancy, Caucasian race, Polish citizenship. Exclusion criteria for both control and study groups were as follows: multiple pregnancy, impaired course of pregnancy (such as gestational hypertension, gestational diabetes), any fetal defect, uterus malformations, cervical insufficiency, general infections, iatrogenic preterm delivery, intrauterine fetal death, chronic disease at mother. At all patients, demographic and clinical data were analysed (Tab. 1). All women were informed about the goal of the study and gave their written consent. The local ethic committee approved the study (Ethic Committee of Poznan University of Medical Sciences).

DNA was extracted from peripheral blood (leukocytes) with the use of QIAmp DNA Blood Mini Kit (QIAGEN Inc, Germany). Genetic analysis was performed with the use of polymerase chain reaction/restriction fragment length polymorphism (PCR/RFLP).

\begin{tabular}{|c|c|c|c|}
\hline & $\begin{array}{l}\text { Study group } \\
\text { PTD } \\
(n=150)\end{array}$ & $\begin{array}{l}\text { Control group } \\
(n=150)\end{array}$ & $\mathbf{p}$ \\
\hline $\begin{array}{l}\text { Age (years) } \\
\text { mean } \pm S D \\
\text { median } \\
\text { minimum/maximum }\end{array}$ & $\begin{array}{l}29.2 \pm 5.6 \\
29 \\
15 / 45\end{array}$ & $\begin{array}{l}29.0 \pm 3.7 \\
28 \\
16 / 41\end{array}$ & ns \\
\hline $\begin{array}{l}\text { Gestational week } \\
(\boldsymbol{g} w) \\
\text { mean } \pm \text { SD } \\
\text { median } \\
\text { minimum/maximum }\end{array}$ & $\begin{array}{l}33.7 \pm 2.8 \\
35 \\
22 / 36\end{array}$ & $\begin{array}{l}39.3 \pm 1.2 \\
39 \\
37 / 41\end{array}$ & $<0.000$ \\
\hline $\begin{array}{l}\text { Systolic } B P(\mathbf{m m H g}) \\
\text { mean } \pm \text { SD } \\
\text { median } \\
\text { minimum/maximum }\end{array}$ & $\begin{array}{l}112.7 \pm 14.6 \\
110 \\
70 / 130\end{array}$ & $\begin{array}{l}109.5 \pm 11.6 \\
110 \\
70 / 130\end{array}$ & ns \\
\hline $\begin{array}{l}\text { Diastolic } B P(\mathbf{m m H g}) \\
\text { mean } \pm \text { SD } \\
\text { median } \\
\text { minimum/maximum }\end{array}$ & $\begin{array}{l}70.7 \pm 11.2 \\
70 \\
50 / 80\end{array}$ & $\begin{array}{l}68.1 \pm 8.9 \\
70 \\
50 / 85\end{array}$ & ns \\
\hline $\begin{array}{l}\text { Parity } \\
1 \\
>1 \\
0\end{array}$ & $\begin{array}{l}60(40.0 \%) \\
79(52.7 \%) \\
11(7.3 \%)\end{array}$ & $\begin{array}{l}73(48.7 \%) \\
13(8.6 \%) \\
64(42.7 \%)\end{array}$ & $<0.001$ \\
\hline $\begin{array}{l}\text { BMI before pregnancy } \\
\text { mean } \pm \text { SD } \\
\text { median } \\
\text { minimum/maximum }\end{array}$ & $\begin{array}{l}22.1 \pm 3.7 \\
22.02 \\
16.4 / 39.5\end{array}$ & $\begin{array}{l}21.6 \pm 2.8 \\
21.03 \\
16.8 / 31.9\end{array}$ & ns \\
\hline $\begin{array}{l}\text { BMI after pregnancy } \\
\text { mean } \pm \text { SD } \\
\text { median } \\
\text { minimum/maximum }\end{array}$ & $\begin{array}{l}26.8 \pm 4.2 \\
25.54 \\
18.7 / 43.9\end{array}$ & $\begin{array}{l}27.1 \pm 3.4 \\
27.28 \\
20.4 / 37.6\end{array}$ & ns \\
\hline $\begin{array}{l}\text { leucocytosis (G/L) } \\
\text { mean } \pm S D \\
\text { median } \\
\text { minimum/maximum }\end{array}$ & $\begin{array}{l}16.4 \pm 5.8 \\
15.7 \\
5.2 / 34.7\end{array}$ & $\begin{array}{l}16.7 \pm 4.6 \\
16.1 \\
7.0 / 30.0\end{array}$ & ns \\
\hline $\begin{array}{l}\text { Type of delivery } \\
\text { Spontaneous delivery } \\
\text { C. section } \\
\text { Vacuum extractor }\end{array}$ & $\begin{array}{l}96(64.0 \%) \\
54(36.0 \%) \\
0(0.0 \%)\end{array}$ & $\begin{array}{l}124(82.7 \%) \\
23(15.3 \%) \\
3(2.0 \%)\end{array}$ & $<0.001$ \\
\hline
\end{tabular}

+3953 C > TIL-1 $\beta$ polymorphism was amplified with the use of the following starters: $F 5^{`}-\mathrm{gTT}$ gTC ATC Aga CTT TgA CC - 3` and R 5 - TTC AgTTCA TAT ggA CCA gA - 3`. $21 \mathrm{bp}$ PCR product was hydrolized with restricitive enzyme Taql (Fermentas, Lithuania) what resulted in obtaining of three genotypes : CC 137, 114 bp, CT 251, 137, 114 bp and TT $251 \mathrm{bp}$.

86 bp VNTR IL-1RN gene polymorphism was amplified with the use of following starters: $F 5-C T C A g C A A C$ ACT CCT AT - $3^{`}$ and R 5 `- TCC Tgg TCT gCA ggT AA - 3` (TiBMolBiol, Poland). Following products of PCR reaction were possible to observe: $154 \mathrm{bp}\left(I L 1 R N^{*} 0\right), 410 \mathrm{bp}\left(I L 1 R N^{*} 1\right)$, $240 \mathrm{bp}\left(I L 1 R N^{*} 2\right), 500 \mathrm{bp}\left(I L 1 R N^{*} 3\right), 325 \mathrm{bp}\left(I L 1 R N^{*} 4\right), 595 \mathrm{bp}$ (IL1RN*5).

Statistical analysis was performed with the use of SPSS 14. $\mathrm{PL}$ for Windows. The frequency of genotypes in both 
groups was compared with the chi-square test with Fisher correction. Correlation of investigated polymorphisms was estimated with chi-square test and Person correlation factor. The mean values were compared with U-Mann-Whitney and ANOVA test. $p<0,05$ was considered statistically significant.

\section{RESULTS}

As to the $+3953 C>T$ IL-1 $\beta$ polymorphism the same frequency of homozygotic CC (56.0 vs. 56,0\%, $p=\mathrm{ns})$ genotype and similar frequency of heterozygotic CT genotype was observed (36.7 vs. 39.3\%, $p=n s)$. Also the frequency of homozygotic mutated TT genotype was similar in both analysed groups (7.3 vs. $4.7 \%, \mathrm{OR}=1.62, p=\mathrm{ns}$ ). The occurrence of both alleles was comparable in both analysed groups ( $C$ allele: 74.3 vs. $75.7 \%, W R=0.93, p=n s ; T$ allele: 25.7 vs. $24.3 \%, \mathrm{WR}=1.07, p=\mathrm{ns}$ ) (Tab. 2).

As to the $86 \mathrm{bp}$ VNTR IL-1RN gene polymorphism in the control and in the study group 10 genotypes were observed. The most frequent genotype was $1 / 1$ (4 repeats in both allele 1), the second one was $1 / 2$ genotype. In the next step of analysis genotypes with frequency $<1 \%$ were put into separate subgroups. Slightly higher frequency of $1 / 1$ IL-1RN in the study group was noted ( $58.7 \%$ vs. $53.3 \%, p=n s)$. An interesting observation was a higher frequency of $2 / 2$ IL-1RN genotype in the control group ( $8.0 \mathrm{vs.} 3.3 \%, \mathrm{OR}=0.39, p=0.06$ ) and allele 2 in the control group ( 25.0 vs. $20.0 \%, O R=0.75$, $p=0.07)$. The frequency of $1 / 4,1 / 5,0 / 2,2 / 3,2 / 4,2 / 5$ genotypes was $<1 \%$ (Tab. 3 ).

There were no statistically significant differences between both analysed groups as to the frequency of investigated polymorphisms and the gestational week of delivery. +3953 C > T IL-1 $\beta$ polymorphism was correlated to the difference between body mass before and after pregnancy ( $p=0.021)$ and BMI before and after pregnancy $(p=0.017)$. There were no other correlations.

\begin{tabular}{|c|c|c|c|c|c|c|c|}
\hline \multirow{2}{*}{$\begin{array}{l}\text { IL-1 } \beta \\
+3953 C>T \\
\text { Genotypes }\end{array}$} & \multicolumn{2}{|l|}{$\begin{array}{l}\text { Study group PTD } \\
(n=150)\end{array}$} & \multicolumn{2}{|l|}{$\begin{array}{l}\text { Control group } \\
(n=150)\end{array}$} & \multirow[t]{2}{*}{ OR } & \multirow[t]{2}{*}{$95 \% \mathrm{Cl}$} & \multirow{2}{*}{$\mathbf{p}$} \\
\hline & Observed value n [\%] & Expected value [\%] & Observed value $\mathrm{n}$ [\%] & Expected value [\%] & & & \\
\hline CC & $84(56.0)$ & 55.2 & $84(56.0)$ & 57.3 & 1.00 & $0.62-1.62$ & 0.54 \\
\hline CT & $55(36.7)$ & 38.2 & $59(39.3)$ & 36.8 & 0.89 & $0.55-1.46$ & 0.36 \\
\hline TT & $11(7.3)$ & 6.6 & $7(4.7)$ & 5.9 & 1.62 & $0.55-5.06$ & 0.23 \\
\hline Total & $150(100.0)$ & 100.0 & $150(100.0)$ & 100.0 & & & \\
\hline \multicolumn{8}{|l|}{ Alleles } \\
\hline C & $223(74.3)$ & - & $227(75.7)$ & - & 0.93 & $0.63-1.37$ & 0.39 \\
\hline $\mathrm{T}$ & $77(25.7)$ & - & $73(24.3)$ & - & 1.07 & $0.73-1.58$ & 0.39 \\
\hline Total & $300(100.0)$ & - & $300(100.0)$ & - & & & \\
\hline
\end{tabular}

\begin{tabular}{|c|c|c|c|c|c|c|c|}
\hline \multirow{2}{*}{ Genotypes } & \multicolumn{2}{|c|}{ Study group PTD $n=150$} & \multicolumn{2}{|l|}{ Control group $n=150$} & \multirow{2}{*}{ OR } & \multirow{2}{*}{$95 \% \mathrm{Cl}$} & \multirow{2}{*}{$\mathbf{p}$} \\
\hline & Observed value $\mathrm{n}$ [\%] & Expected value [\%] & Observed value $n$ [\%] & Expected value [\%] & & & \\
\hline $1 / 1$ & $88(58.7)$ & 59.3 & $80(53.3)$ & 51.4 & 1.19 & $0.73-1.93$ & 0.27 \\
\hline $1 / 2$ & $48(32.0)$ & 30.8 & $48(32.0)$ & 35.8 & 0.97 & $0.58-1.62$ & 0.50 \\
\hline $1 / 3$ & $5(3.3)$ & 2.5 & $7(4.7)$ & 3.9 & 0.68 & $0.17-2.59$ & 0.37 \\
\hline $2 / 2$ & $5(3.3)$ & 4.0 & $12(8.0)$ & 6.3 & 0.39 & $0.10-1.22$ & 0.06 \\
\hline Other & $4(2.7)$ & 3.4 & $3(2.00)$ & 2.6 & - & - & - \\
\hline Total & $150(100.0)$ & 100.0 & $150(100.0)$ & 100.0 & & & \\
\hline Alleles & $\mathrm{n}(\%)$ & & $n(\%)$ & & & & \\
\hline 1 & $231(77.0)$ & - & $215(71.7)$ & - & 1.28 & $0.87-1.88$ & 0.10 \\
\hline 2 & $60(20.0)$ & - & $75(25.0)$ & - & 0.75 & $0.49-1.11$ & 0.07 \\
\hline 3 & $5(1.6)$ & - & $8(2.7)$ & - & 0.61 & $0.15-2.16$ & 0.28 \\
\hline Other & $4(1.4)$ & - & $2(0.6)$ & - & 2.01 & $0.29-22.39$ & 0.34 \\
\hline Total & $300(100.0)$ & & $300(100.0)$ & & & & \\
\hline
\end{tabular}




\section{DISCUSSION}

Nowadays, it is believed that the most frequent reason of PTD are subclinical infections related to cytokine activation. Special attention has been paid to IL-1 $\mathrm{b}$ activity which is a mediator of inflammatory reactions and main pro-inflammatory cytokine. That is why genetic variants of this cytokine have been considered in the studies on PTD etiology. Carriers of mutated $T$ allele of +3953 C > T IL-1 $\beta$ polymorphism may be more susceptible to PTD risk because of elevated IL- $1 \beta$ concentration [8].

In the presented study +3953 C > TIL-1 $\beta$ polymorphism no correlation to increased risk of PTD was noted. The frequency of mutated TT genotype in the study group was only slightly higher than in the control group and observed differences were not statistically significant (7.3 vs. 4.7\%, $p=\mathrm{ns})$.

Obtained results are complied with other authors' observations. In the study of Kalinka et al. performed in the Polish population no correlation of this polymorphism to PTD risk was revealed [9]. Kalish et al. analysed the influence of mutated allele of +3953 C $>$ TIL-1 $\beta$ polymorphism carrierstate at mother and fetus on the risk of PTD. There was no such correlation [10].

In the study of Edwards et al. cervical discharge, peripheral blood and umbilical blood were the study material. The study group involved patients with PTD between 23-32 gw. Higher concentration of IL- $1 \beta$ in cervical discharge was correlated to the increased risk of PTD. And the carrier-state of $T$ allele of $+3953 C>$ TIL-1 $\beta$ polymorphism did not influence the concentration of IL-1 $\beta$ in cervical discharge as well as on the risk of PTD [11].

Other conclusions concern study which involved women from Danish population. Hollegard et al estimated the influence of genetic variants of three cytokines: TNF- $\alpha$, IL $1 \beta$ and IL- 6 on the risk of PTD. To the study group 62 women with PTD were enrolled and to the control group - 55 women who delivered $>37 \mathrm{gw}$. The authors concluded that at carriers of the rare $T$ allele of $-857 C>T$ TNF-a polymorphism and mutated homozygotes of $31 T>C I L 1 \beta$ and $-511 C>T$ IL1 $\beta$ are in the group of increased risk of PTD [12].

It has been already suggested that cytokine receptor binding may be blocked by its antagonists. It has been proven that IL-1RA inhibits IL1 $\beta$ activity. At women carriers of IL-1RN*2 allele higher concentration of IL-1RA is observed. That is why it correlates lower risk of PTD $[9,13]$.

In the presented study higher frequency of

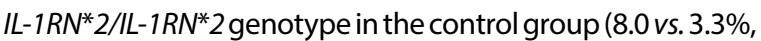
$p=0.06$ ), as well as $I L-1 R N^{*} 2$ allele in the control group ( 25.0 vs. $20.0 \%, p=0.07$ ) suggests its protective role as to the risk of PTD. Obtained in our study results stay in the opposite to observations made by other authors.

In the study of Kalinka et al performed on Polish population ( 62 patients with PTD and 63 women from the study group) increased risk of PTD at the presence of IL$1 R N^{*} 2$ allele was observed [9]. Similar results were obtained in the study concerning Brazilian population which has again proven that at carriers of $I L-1 R N^{*} 2$ allele the risk of PTD is increased [14].

Convergent results were also obtained by Muthra et al who investigated women from Caucasian and Afro-American races. The higher risk of PTD was observed at mothers with $I L-1 R N^{*} 2$ allele. All patients from this study with $I L 1 R N^{*} 2 / I L 1 R N^{*} 2$ genotype delivered preterm [15].

In the study of Genc et al. correlation between $I L-1 R N$ polymorphism, the presence of bacterial flora in vagina and PTD risk was performed. The material (vaginal bacterial swab, genetic analysis) was taken from 212 women between 18 and $22 \mathrm{gw}$. Carrier-state of $I L-1 R N^{*} 2$ allele was related to increased vaginal $\mathrm{pH}$ and increased risk of PTD [16].

Nowadays PTD is considered to be one of the complex human diseases, that is why in its etiology correlation of genetic, environmental, family medical history should be considered. In the genetic studies concerning PTD the influence of alleles with high frequency and small effect, but rarely with big effect is considered (point to critical effect) [Esplin 2005, Verner 2005]. It is believed that the influence of genetic factors on the PTD occurrence may be considered as sure. Immunological reactions are integral part of processes leading to delivery initiation and response to infection may be modulated by genetic variants. Further studies and investigation the genetic relation may help to create a diagnostic test which will point outpatients with high risk of PTD.

\section{CONCLUSIONS}

1. The $+3953 C>$ T polymorphism of IL- $1 \beta$ gene is probably not connected with the risk of preterm delivery.

2. The study results points to the possible modulating effect of mutated IL-1RN* 2 allele ( $86 \mathrm{bp} \mathrm{VNTR} \mathrm{polymorphism)}$ of IL-1RN gene in decreased risk of preterm delivery.

\section{REFERENCES}

1. Drews-Piasecka E, Seremak-Mrozikiewicz A, Barlik M, et al. The significance of genetic factors in aetiology of preterm delivery. Ginekol Pol. 2007; 78(4): 317-323, indexed in Pubmed: 17621996.

2. Ward K, Argyle V, Meade M, et al. The heritability of preterm delivery. Obstet Gynecol. 2005; 106(6): 1235-1239, doi: 10.1097/01. AOG.0000189091.35982.85, indexed in Pubmed: 16319246.

3. Ward K. Genetic factors in preterm birth. BJOG. 2003; 110 Suppl 20: 117, indexed in Pubmed: 12763127.

4. WeiSQ, FraserW, LuoZC. Inflammatory cytokines and spontaneous preterm birth in asymptomatic women: a systematic review. Obstet Gynecol. 2010; 116(2 Pt 1): 393-401, doi: 10.1097/AOG.0b013e3181e6dbc0, indexed in Pubmed: 20664401.

5. Rozwadowska N, Fiszer D, Kurpisz M. [Function of the interleukin-1 gene system in immunomodulation, apoptosis and proliferation in the male gonad]. Postepy Hig Med Dosw (Online). 2005; 59: 56-67, indexed in Pubmed: 15761387.

6. Tarlow JK, Blakemore Al, Lennard A, et al. Polymorphism in human IL-1 receptor antagonist gene intron 2 is caused by variable numbers of 
an 86-bp tandem repeat. Hum Genet. 1993; 91(4): 403-404, indexed in Pubmed: 8500797.

7. Vamvakopoulos J. Interleukin 1 gene polymorphisms. Ann Rheum Dis. 2001; 60(7): 718-719, indexed in Pubmed: 11436858.

8. Baggia S, Gravett MG, Witkin SS, et al. Interleukin-1 beta intra-amniotic infusion induces tumor necrosis factor-alpha, prostaglandin production, and preterm contractions in pregnant rhesus monkeys. J Soc Gynecol Investig. 1996; 3(3): 121-126, doi: 10.1177/107155769600300304, indexed in Pubmed: 8796819.

9. Kalinka J, Bitner A. [Selected cytokine gene polymorphisms and the risk of preterm delivery in the population of Polish women]. Ginekol Pol. 2009; 80(2): 111-117, indexed in Pubmed: 19338208.

10. Kalish RB, Vardhana S, Gupta M, et al. Interleukin-1 receptor antagonist gene polymorphism and multifetal pregnancy outcome. Am J Obstet Gynecol. 2003; 189(4): 911-914, indexed in Pubmed: 14586324.

11. Edwards RK, Ferguson RJ, Duff $P$. The interleukin- 1 beta +3953 single nucleotide polymorphism: cervical protein concentration and preterm delivery risk. Am J Reprod Immunol. 2006; 55(4): 259-264, doi: 10.1111/j.1600-0897.2005.00358.x, indexed in Pubmed: 16533337.

12. Hollegaard MV, Grove J, Thorsen P, et al. Polymorphisms in the tumor necrosis factor alpha and interleukin 1-beta promoters with possible gene regulatory functions increase the risk of preterm birth. Acta Obstet Gynecol Scand. 2008; 87(12): 1285-1290, doi: 10.1080/00016340802468340, indexed in Pubmed: 18951205.

13. Genc MR, Onderdonk A. Endogenous bacterial flora in pregnant women and the influence of maternal genetic variation. BJOG. 2011; 118(2): 154-163, doi: 10.1111/j.1471-0528.2010.02772.x, indexed in Pubmed: 21054765.

14. Chaves $\mathrm{JH}$, Babayan $\mathrm{A}$, Bezerra $\mathrm{Cd}$, et al. Maternal and neonatal interleukin-1 receptor antagonist genotype and pregnancy outcome in a population with a high rate of pre-term birth. Am J Reprod Immunol. 2008; 60(4): 312-317, doi: 10.1111/j.1600-0897.2008.00625.x, indexed in Pubmed: 18754838.

15. Murtha AP, Nieves A, Hauser ER, et al. Association of maternal IL-1 receptor antagonist intron 2 gene polymorphism and preterm birth. Am J Obstet Gynecol. 2006; 195(5): 1249-1253, doi: 10.1016/j. ajog.2006.09.002, indexed in Pubmed: 17074546

16. Genc MR, Vardhana S, Delaney ML, et al. MAP Study Group. Relationship between a toll-like receptor-4 gene polymorphism, bacterial vaginosisrelated flora and vaginal cytokine responses in pregnant women. Eur J Obstet Gynecol Reprod Biol. 2004; 116(2): 152-156, doi: 10.1016/j. ejogrb.2004.02.010, indexed in Pubmed: 15358455. 